Acta Theriologica 39 (4): 379-388, 1994.

PL ISSN 0001-7051

\title{
Superpositions of regular moults in Mus musculus
}

\author{
L. Javier PALOMO, J. Mario VARGAS and F. Javier POZUETA
}

Palomo L. J., Vargas J. M. and Pozueta F. J. 1994. Superpositions of regular moults in Mus musculus. Acta theriol. 39: 379-388.

The number, topographic sequence and duration of the moults of the coat of Mus musculus Linnaeus, 1758 are analysed using wild specimens from collections and albino specimens born and kept in the laboratory. Mice undergo an uninterrupted series of regular moults throughout its life. Each has a typical duration. The juvenile moult is the fastest and in all cases the speed of moulting is unconstant. At first the rate is accelerated but it frequently decelerates, and even pauses, so that some parts of the body, mainly the cephalic area, do not moult. This pause leads to a superposition of waves of different moults with the coexistence of 3 or more coats. The superpositions, revealed by dying the laboratory animals' coats, could be the reason why previous authors have claimed the existence of irregular moults in $M$. musculus. With the wild specimens, despite the fact that the inner surface of the skin yields less information, moulting patterns, similar to those described in the laboratory specimens, may be detected.

Department of Animal Biology, Faculty of Sciences, University of Málaga, 29071 Málaga, Spain

Key words: Mus musculus, moult, coat

\section{Introduction}

Most wild murids display patterns of moulting which are fairly uniform. Kryltzov (1964), indicated that the growth of the first moult follows a sublateral pattern in most cases. According to this author, this is a genotypically well established characteristic. In the wild species, as is the case of Mus spretus (España et al. 1985, Palomo and Vargas 1988a, b), Apodemus sylvaticus (Fullagar 1967, Schmidt 1970, Sans-Coma et al. 1987a) and Rattus rattus (Sans-Coma et al. 1987b), two regular symmetric moults (the juvenile and the intermediate) take place after birth, followed by an indefinite series of partial and irregular moults. However, in some commensal species, the pattern of moulting seems to be different. For example, in Rattus norvegicus there are more than two regular moults, which develop in a continuous manner (Becker 1952, Conte 1986).

In the case of the house mouse Mus musculus Linnaeus, 1758, the information available is rather more controversial. In fact, there is no full agreement over the number, type or duration of the moults. In this species Dry (1926) declared that two regular moults (the juvenile and the intermediate), and a series of subsequent 
irregular moults take place. However, López-Fuster (1978), analysing wild specimens, only detected the first regular moult, followed by a series of partial and irregular moults. The latter interpretation may have been due to insufficient data and to the similarity between the sequence of both regular moults. Recently Pozueta et al. (1991) demonstrated experimentally that M. musculus undergoes uninterrupted succession of regular moults from birth until death. In this study the topographic sequence, age and duration of the moults of the house mouse are described in detail. The different patterns defined, all of them regular, refer to certain peculiarities in the wave of moulting on the back of the animal. The sequence is fairly uniform although there are some individual variations in development. In all cases, the moult commences in the axial region, progresses from the front to the back until the whole belly is covered, moves up to the back and concludes in the cephalic regions, at the base of the tail and in the areas of the extremities. Once the animal has finished the moult its colour is white with greyish tones, which indicate an incomplete culmination of the moulting process. Based on this criterion, all regular moults of $M$. musculus, though total and homogeneous, are incomplete.

The aim of this study is to demonstrate the existence of partial superpositions of moults and coats of fur throughout the life of the animal. This phenomenon, hitherto unrecognized in mice, affects almost all specimens to a greater or lesser scale, which may explain why previous authors have mistaken superpositions for sequences of irregular moults when analysing the inner surface of the skins of $M$. musculus.

\section{Materials and methods}

Totally, 102 albino house mice $M$. musculus (strain BALB/c) were used ( 46 males, 56 females) from 23 litters born between March 1986 and March 1987. Both the breeding pairs and the litters were kept in captivity under uniform feeding conditions and in natural light and temperature. For comparison, 216 wild specimens were studied (111 males, 105 females), from the collections of the Animal Biology Department of the University of Málaga. These animals had been captured in human environments in different locations in the south of the Iberian Peninsula, between 1982 and 1986. The monthly distribution of the captures is as follows: January: $11 \mathrm{~m}, 7 \mathrm{f}$; February: $9 \mathrm{~m}, 12 \mathrm{f}$; March: 6 m, 10 f; April: 8 m, 6 f; May: 10 m, 7 f; June: 1 m, 1 f; July: 12 m, 13 f; August: 17 m, 13 f; September: $11 \mathrm{~m}, 11 \mathrm{f}$; October: $13 \mathrm{~m}, 10 \mathrm{f}$; November: $5 \mathrm{~m}, 4 \mathrm{f}$; December: $8 \mathrm{~m}, 11 \mathrm{f}$.

In sacrificed animals, a traditional and indirect method is used. The distribution and intensity of melanin accumulation in the hair root before passing through to the shaft indicate the stage of moult which the animal is undergoing (Becker 1952). However, to detect the melanin in the dermis it is necessary to kill the animal, and so only an instantaneous information of the process can be obtained. The topographic sequence of the moult only can be reconstructed by studying a large number of animals, and even then, only approximately.

In live specimens, moulting was detected by dying the fur during the latency stage, which is the period of time which elapses after the hair has completed growth and before moulting commences (Butcher 1934). The method used was described by Johnson (1958) and modified by Palomo and Vargas $(1988 \mathrm{a}, \mathrm{b})$. This procedure has the advantage of not affecting either the texture of the skin or the skin itself (Martin-Dennis and Peitz 1981). The continuous observation of the coats revealed the 
sequence of emergence of new hairs with their original white colour. The coats were dyed immediately after the completion of each moulting process, with the aim of detecting superpositions of consecutive coats.

\section{Results}

Specimens bred in the laboratory were born hairless and with a pinkish colouring. At 14 days of age the body was completely covered with hair. The final departure from the nest took place at approximately 18 days of age, when the juvenile coat was fully grown. At this age the animals were dyed and individualized. Some specimens, studied from birth to death, undergo a continuous series of regular moults. As a whole, three groups of different moults were established: the first moult or juvenile moult (with 4 different patterns), the second moult or intermediate moult (with three patterns) and a third group consisting of the third and subsequent moults, all very similar (also with three different patterns).

Each moulting process in the animals' lifetime had a typical duration. The juvenile moult was the fastest (Table 1 ) and in all cases the moulting wave moves at a unconstant speed. At first the moult is fast but it frequently decelerates and even pauses, so some regions of the body do not moult, mainly in the cephalic area. The period of pause, which is the time which elapses from moulting decelerates until it is completed, is also far shorter in the first moult than in subsequent ones (Table 1). The pause sometimes leads to the cephalic area not moulting when the next moulting process has commenced. This results in the superposition of two different moults, with coexistence of three coats. In order to demonstrate this superposition the animals whose moulting processes had stabilized (normally in the cephalic area) were completely dyed. If the animal began a new moulting process at the level of the belly before the head had finished moulting, it means a case of superposition has been produced.

In Table 2 the frequency of superpositions in the different moults studied is shown. This frequency increases with age of the animals as a result of the parallel increase in the period of pauses. The superposition of two moults is quite frequent and in some cases up to 4 coats coexist owing to the superposition of three waves

Table 1. Duration (average \pm SD) of moulting and pause periods (in days) in the three first moults detected in Mus musculus. $n$ - sample size.

\begin{tabular}{lccl}
\hline Moult & $n$ & $\begin{array}{c}\text { Moulting } \\
\text { (days) }\end{array}$ & $\begin{array}{l}\text { Pause } \\
\text { (days) }\end{array}$ \\
\hline 1st & 35 & $14.5 \pm 4.3$ & $23.4 \pm 6.2$ \\
2nd & 67 & $29.2 \pm 7.2$ & $32.4 \pm 7.1$ \\
3th & 36 & $31.3 \pm 6.7$ & $43.4 \pm 8.5$ \\
\hline
\end{tabular}

Table 2. Frequency of superpositions (in \%) among different moults studied. $n$-sample size.

\begin{tabular}{lrl}
\hline Overlaped moults & $\%$ & $\mathrm{n}$ \\
\hline $1-2$ & 16 & 40 \\
$2-3$ & 71 & 48 \\
$3-4$ & 78 & 28 \\
$2-3-4$ & 8 & 13 \\
$3-4-5$ & 3 & 33 \\
\hline
\end{tabular}




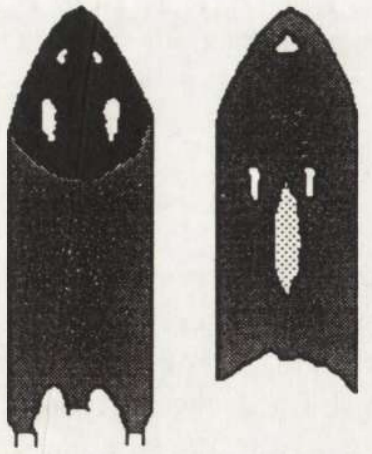

a

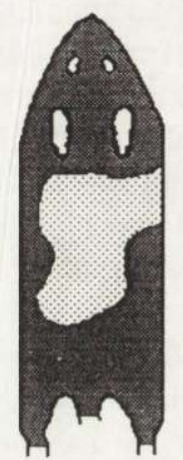

C
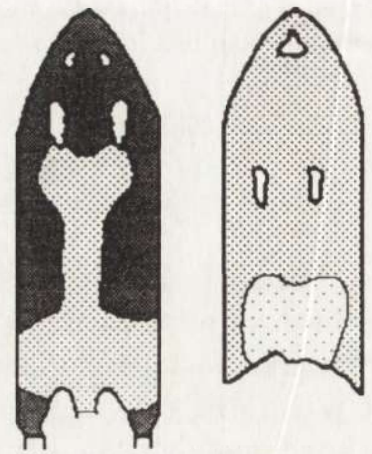

b
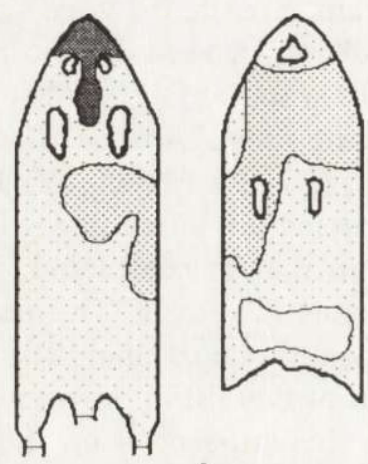

d

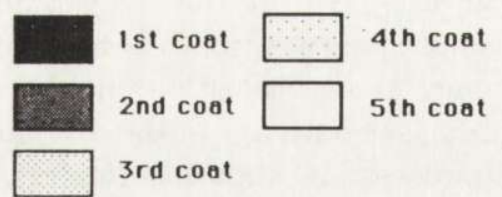

Fig. 1. Moult superpositions detected by consecutively dying the pelage of Mus musculus. (a) superposition between moults 1st and 2nd, (b) and (c) superposition between moults 2nd and 3rd, (d) multiple superposition among moults 2nd, 3rd and 4th. Each coat (from first to fifth) is represented with a different shading.

of different moults. However, animals with multiple superpositions were rare and the percentage of affected areas minimal and, at times, difficult to detect.

Figure 1 shows some examples of superpositions in moults detected during this study. The simplest case is that of specimen a, which had already commenced the intermediate moult (in the belly region) before completing the juvenile moult. The cephalic area still shows the remains of the juvenile coat, the intermediate coat can be seen on practically all the body and only the belly region shows some signs 

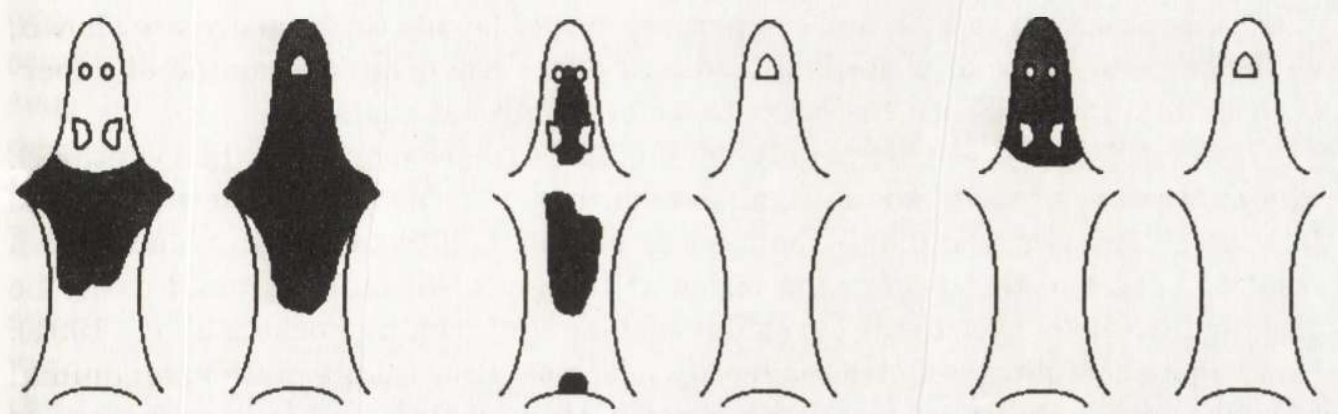

a

b

C
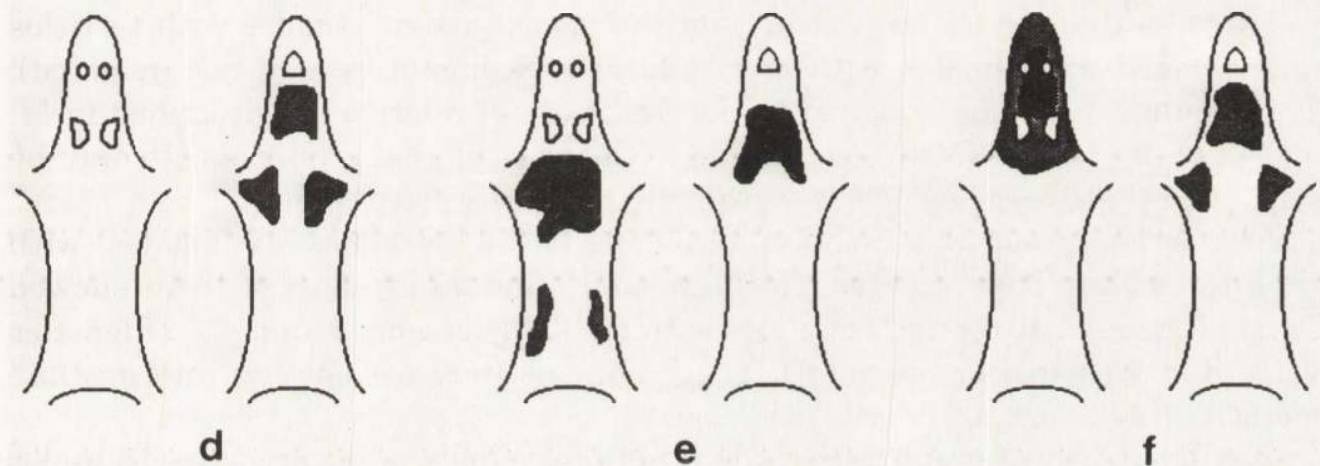

f

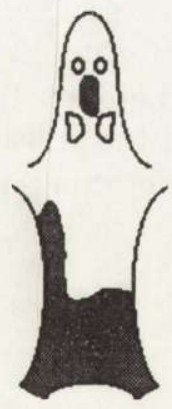

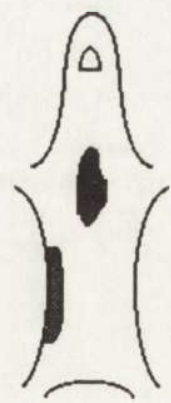

g
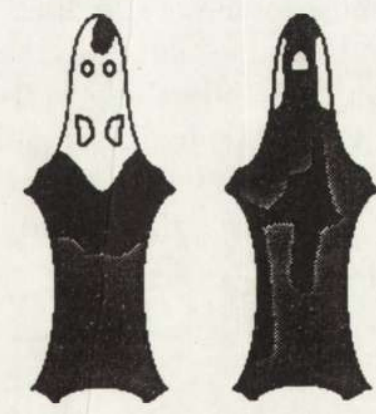

h

Fig. 2. Melanin accumulation patterns in inner surface of skin in wild Mus musculus during different moults: juvenile moult ( $a, b$ and $c$ ), intermediate moult (d, e and $f$ ), third or subsequent moults ( $g$ and h). The difference in darkness is related with the amount of melanin accumulated on the skin. 
of the adult coat. In cases b and c superpositions of moults 2nd and 3rd are shown, with the coexistence of coats $2 \mathrm{nd}$, 3rd and 4 th. Case $\mathrm{d}$ is an example of superposition of 3 moults, with the coexistence of 4 different coats.

Of the 216 wild specimens analysed, 79 (36.6\%) were moulting when captured. The study of their coats shows regular moulting patterns, similar to those of the laboratory animals: the moult commences in the axillary region, it avances from front to back and the head is the last part to moult. All animals could easily be assigned to one of the stages of regular moults described by Pozueta et al. (1991). It is a more complicated to try to identify which moult is taking place in an animal by examining only its coat and the inner surface of the skin. It is necessary to take into account some metric data (HBL - head and body length, weight, DIA diastema length, CBL - condylobasal length) and state of sexual activity. Such measurements led us to establish groups with the animals studied.

The first group was made up of 14 animals ( 8 males, 6 females) of small size, weight less than $10 \mathrm{~g}$ and without signs of sexual activity (males with testicles undescended and females with uteri and ovaries immature and not irrigated). These animals may be assigned to the first class of relative age described in $M$. musculus by Laurie (1946), consisting exclusively of young animals. It may be concluded that these specimens were undergoing the juvenile moult.

The second group was made up of 30 specimens ( 14 males, 16 females) with an intermediate body size (weight between 10 and $20 \mathrm{~g}$ ); most of them showed signs of sexual activity (93\% of males with testicles descended and $50 \%$ of females with uteri irrigated or pregnant). These animals were assigned to intermediate moult.

Finally the third group was made up of 35 sexually adult animals (18 males and 17 females). All of them had reached the adult body size (weight above $20 \mathrm{~g}$ ) and were undergoing the third or subsequent moult. It was not possible to determine which moult the animals were undergoing.

Figure 2 shows some of the diagrams obtained from studying the inner surface of wild animals skins. The specimens chosen illustrate different stages in the process of moulting and belong to the three established groups: the juvenile moult ( $\mathrm{a}, \mathrm{b}$ and $\mathrm{c}$ ), the intermediate moult ( $\mathrm{d}$, e and $\mathrm{f}$ ) and the third and subsequent moults ( $g$ and $h$ ). In some of them the superposition of different moults can be seen, for example, cases e, $f, g$ and h clearly display the coexistence of more than 2 different coats.

\section{Discussion}

The juvenile coat of $M$. musculus is acquired at the age and following the patterns described by other authors (Dry 1926, Borum 1954, Sykora 1963, Reichstein 1978). They all agree that the growth of the first coat is practically 
over by the time the animal leaves the nest (2-3 weeks of life). From then on $M$. musculus undergoes an uninterrupted succession of regular moults, with similar sequences, although showing individual variations in development. The patterns described for the laboratory specimens do not agree exactly with those found by Borum (1954), who detected 5 different patterns in the first moult (only 2 concur with those found in this study, see also Pozueta et al. 1991).

The study of the moulting process in wild animals is more complicated. In some species of mammals the moulting phenomena seem to be geared to environmental variations by way of the hormonal system, in a similar manner to the control of the sexual cycle (Johnson 1984). They constitute the seasonal coat changes which appear, for example, in some species of genera Microtus (Stein 1960, Khateeb and Johnson 1971) and Apodemus (Stein 1960, Saint-Girons 1967). However, it does not necessarily imply that the seasonal climatic variations, in their wider sense, cause the moulting process. Some authors argue for a certain degree of genetic control (related to age) on moulting. So, for example, the regular moults in some murids happen, although with wide individual differences, at specific ages, independently of seasons (Schmidt 1970, Sans-Coma et al. 1987a, b, Palomo and Vargas 1988a, Pozueta et al. 1991). Seasonal moults are usually related to species whose reproduction take place during limited (favourable) periods of the year and accordingly, the more restricted the reproduction is, the higher the superposition of seasons and moults must be. Nevertheless, it remains unclear to what extent the environmental influence is supplanting a possible genetic determinism or whether it is on the contrary (Palomo and Vargas 1988b).

In the present study there were wild animals moulting and with signs of sexual activity throughout the year, and although the percentages vary during the course of the year there is no significant concentration in any specific period. Moreover, there is no correlation between these values. Further, in albino bred mice there were no significant differences of moulting in relation to sex or month of study (see also Borum 1954, Sykora 1963). For all these reasons the hypothesis of a seasonal moult in its strict sense, both in laboratory and commensal wild populations of $M$. musculus, may be ruled out.

In murids, once the adult coat has been acquired, the moults were characterized by irregularity in their appearance and duration as well as in their topography. The irregular moult occurs more or less continuously throughout the life of most species (see Stein 1960, Fullagar 1967, Sans-Coma et al. 1987a, b, Palomo and Vargas 1988b) and even in M. musculus (Dry 1926, López-Fuster 1978). In this study, irregular moults such as those described above were not detected in either the wild or the laboratory specimens. What is the reason for this divergence? Most of the authors mentioned above used the appearance of melanin on the inner surface of the skin as an indicator of moult. This is the only method that can be applied to dead animals. However, the great disadvantage of this method is that it only offers a instantaneous view of the moulting process and the sequences obtained can give an unreal and distorted impression. In fact, such common 
phenomena as the superposition of moults are difficult to detect (Fig. 1). Moreover, in wild animals, the accumulation of melanin in different zones of the inner surface of the skin may give rather confusing pictures. So, the images obtained from the study of both wild and laboratory animals with superpositions of regular moults (Fig. 2e, g and h) can show a certain irregularity. Sometimes they are even similar to patterns which other authors consider to be irregular (Dry 1926, Fullagar 1967, López-Fuster 1978, Sans-Coma et al. 1987a, b). This similarity may have been the cause of confusion for a long time, at least in the particular case of M. musculus.

Adult M. musculus and $R$. norvegicus (Becker 1952, Conte 1986) seem to undergo only a continual series of regular moults which also display a narrow margin of topographic variation. The difference between this model and that described for wild species with adult moults of irregular type, suggests that the recurrence of regular moults in $M$. musculus and $R$. norvegicus could be due to the high homozygosis which a commensal life in captivity promotes in both natural and laboratory communities of both species.

Superposition between moults in the house mouse is a common phenomenon (Table 2), which has not been detected todate in other murids. Palomo and Vargas (1988a), with this method, did not find superpositions between the juvenile and the intermediate moults in $M$. spretus. In this species the intermoult period lasted between 7 and 17 days. The animals always finished both moults. Once the adult coat was acquired, the moults were totally irregular, in both their topography as well as in their appearance and duration (Palomo and Vargas 1988b). Borowski $(1968,1973)$ in representatives of the genera Sorex and Neomys distinguished three types of moults: complete (whole skin), wave type (only a narrow band of skin) and irregular or senile. The two last moults were frequently interrupted in different parts of the body and consequently two types of coat coexisted. This event is similar to described in $M$. musculus. The biological meaning of superpositions is, by the moment, unknown.

Alterations and aberrations in the established patterns have been detected only in a few cases, and they have thus been classified as atypical moults. In some cases they are due to pathological causes (infectious illness) which somehow affect the hormonal balance. Similar cases have been described by Fraser and Nay (1950), especially in pregnant $M$. musculus which further points towards the idea of possible alterations in the hormonal balance.

In all the laboratory mice, the final result of moulting was the same and the colour of the coats was whitish with certain greyish tones. This is due to the fact that after any moult the animal preserves, uniformly distributed, old hairs since many follicles retain these hairs, which then coexist with new hairs that had grown. This was also described by Palomo (1988) in M. spretus. In both species, the animals undergo a total, homogeneous moult, which is however, incomplete as not all the hairs are renewed during the moult. 


\section{References}

Becker K. 1952. Haarwechselstudien an Wanderratten (Rattus norvegicus). Biol. Zentrablatt 71: 626-640.

Borowski S. 1968. On the moult in the common shrew. Acta theriol. 13: 483-498.

Borowski S. 1973. Variations in coat and colour in representatives of the genera Sorex L. and Neomys Kaup. Acta theriol. 18: 247-279.

Borum K. 1954. Hair pattern and hair succession in the albino mouse. Acta Pathol. Microbiol. Scand. 34: 521-541.

Butcher E. O. 1934. The hair cycles in the albino rat. Anat Rec. 61: 5-59.

Conte L. 1986. Estudio biológico de la rata común, Rattus norvegicus Berkenhout 1769 en el Delta del Ebro (Tarragona). Tesis de Licenciatura, Univ. Barcelona: 1-243.

Dry F. W. 1926. The coat of the mouse (Mus musculus). J. Genetics 16: 287-340.

España M., Palomo L. J., Zamorano E. and Sans-Coma V. 1985. Über Haarwechsel und Haarkleid von Mus spretus Lataste, 1883 aus Südspanien. Spixiana 8: 1-16.

Fraser A. S. and Nay T. 1950. Growth of the mouse coat. Austral. J. Biol. Sci. 6: 1-15.

Fullagar P. J. 1967. Moult in field mice and the variation in the chest markings of Apodemus sylvaticus (Linné, 1758) and Apodemus flavicollis (Melchior, 1854). Säugetierkdl. Mitt. 15: 138-149.

Johnson E. 1958. Quantitative studies of hair growth in the albino rat. I. Normal males and females. J. Endocrin. 16: 337-350.

Johnson E. 1984. Seasonal adaptive coat changes in mammals. Acta zool. Fenn. 171: 7-12.

Khateeb A. A. and Johnson E. 1971. Seasonal changes of pelage in the vole (Microtus agrestis). I. Correlation with changes in endocrine glands. Gen. Com. Endocr. 16: 217-228.

Kryltzov A. L. 1964. Moult topography of Microtinae, other rodents and lagomorphs. Z. Säugetierk. 29: $1-17$.

Laurie E. M. O. 1946. The reproduction of the house mouse (Mus musculus) living in different environments. Proc. Royal Soc. B, 133: 248-281.

López-Fuster M. J. 1978. Sobre Mus musculus Linnaeus, 1758 en el Nordeste ibérico. Tesis de Licenciatura. Univ. Barcelona: 1-189.

Martin-Denis G. and Peitz B. 1981. Development of adult pelage in normal and hormone-injected spiny mice (Acomys cahirinus). J. exp. Zool. 218: 381-386.

Palomo L. J. 1988 Etude descriptive des poils de Mus spretus Lataste, 1883. Rev. suisse Zool. 95: 505-512.

Palomo L. J. and Vargas J. M. 1988a. Deroulement topographique et temporel des mues reguliers de la souris a queue courte Mus spretus Lataste, 1883. Mammalia 52: 75-83.

Palomo L. J. and Vargas J. M. 1988b. On the irregular moult in the Algerian mouse, Mus spretus Lataste, 1883. Acta theriol. 33: 67-86

Pozueta F. J., Palomo L. J. and Vargas J. M. 1991. Regularidad topográfica en las mudas del ratón casero Mus musculus Linneo, 1758 (Rodentia, Muridae). Zoologica Baetica 2: 71-84.

Reichstein H. 1978. Mus musculus Linnaeus, 1758 - Hausmaus. [In: Handbuch der Säugetiere Europas. I. J. Niethammer and F. Krapp, eds]. Akademische Verlagsgesellschaft, Wiesbaden: 421-451

Saint-Girons M. C. 1967. Etude du genre Apodemus Kaup, 1829 en France (suite et fin). Mammalia 31: $55-100$.

Sans-Coma V., Rosado L. M. and Gosálbez J. 1987a. Un estudio de la morfometría y del comienzo de la actividad reproductora de Apodemus sylvaticus (L. 1758) en la Península Ibérica basado en la consideración de los pelajes y las mudas como indicadores de la edad. [In: Mamíferos y helmintos. Volumen homenaje al Prof. Dr. Dr. Herman Kahmann en su 81 aniversario. V. Sans-Coma, S. Mas-Coma and J. Gosálbez, eds]. Ed. Ketres, Barcelona: 89-98.

Sans-Coma V., Zamorano E., Vargas J. M. and Antúnez A. 1987b. Über den Haarwechsel freilebender Hausratten Rattus rattus (L. 1758), in Südspanien. Zool. Abh. Mus. Tierk. Dresden 42: 125-136. 
Schmidt E. 1970. Untersuchungen über Fortplanzung, postnatale Entwicklung und Kreuzbarkeit von Waldmaus (Apodemus sylvaticus Linné, 1758) und Gelbhausmaus (Apodemus flavicollis Melchior, 1834) unter Laboratoriumsbedingungen. Diss. Ludwig-Maximilians Univ., München: 1-169.

Stein G. H. W. 1960. Zum Haarwechsel der Feldmaus, Microtus arvalis (Pallas, 1778) und weiterer Muroidea. Acta theriol. 4: 27-43.

Sykora I. 1963. Juvenile moulting in laboratory mice. Acta Soc. Zool. Bohemoslov. 27: 159-164 .

Received 31 May 1993, revised 23 May 1994, accepted 3 June 1994. 